\title{
THE FREQUENCY OF USE OF COMBINATIONS OF ANTIHYPERTENSIVE DRUGS IN PATIENTS WITH DIFFICULT- TO-CONTROL HYPERTENSION ON THE BACKGROUND OF BIOFEEDBACK AND PACED BREATHING AND HEART RATE VARIABILITY
}

\author{
Tymoshenko O. S. ${ }^{I}$, Yabluchansky M. I. ${ }^{I}$, Bilchenko O. V. ${ }^{1,2}$ \\ ${ }^{1}$ V. N. Karazin Kharkiv National University, Kharkiv, Ukraine \\ ${ }^{2}$ Kharkiv Medical Academy of Postgraduate Education, Kharkiv, Ukraine
}

The frequency of administration of combinations of antihypertensive drugs and its changes at different stages of observation was studied in 60 patients with difficult-to-control arterial hypertension (DTCAH) (32 men and 28 women) aged 59.0 \pm 9.4. All patients were randomly divided into two subgroups: biofeedback (BFB) in the loop of paced breathing (PB) and heart rate variability (HRV) (33 patients) - basic subgroup, subgroup of comparisons (27 patients). Determined that patients with DTCAH in the subgroup of patients with the BFB in the loop of $\mathrm{PB}$ there has been a reduction of four-component antihypertensive therapy to three-component and in the subgroup of comparisons the frequency of the appointment of a four-component therapy was increased. At the same time, it was found that the addition of drug therapy with regular BFB sessions in the loop of $\mathrm{PB}$ contributed to the potentiation of the antihypertensive effect in patients with DTCAH. It is concluded that the BFB in the loop of PB and HRV can be used as a technology to improve the efficiency of control of blood pressure in patients with DTCAH.

KEY WORDS: difficult-to-control arterial hypertension, heart rate variability, biofeedback, paced breathing

\section{ЧАСТОТА ПРИЗНАЧЕННЯ КОМБІНАЦИЙ АНТИГІПЕРТЕНЗИВНИХ ПРЕПАРАТІВ У ПАЦІЕНТІВ 3 ВАЖКО КОНТРОЛЬОВАНОЮ АРТЕРІАЛЬНОЮ ГІПЕРТЕНЗІЕЮ НА ТЛІ ПРОВЕДЕННЯ СЕАНСІВ БІОЛОГІЧНОГО ЗВОРОТНОГО ЗВ' ЯЗКУ В КОНТУРІ МЕТРОНОМИЗИРОВАННОГО ДИХАННЯ}

Тимошенко О. С. ${ }^{1}$, Яблучанський М. I. ${ }^{1}$, Більченко О. В. ${ }^{1,2}$

${ }^{1}$ Харківський національний університет імені В. Н. Каразіна, м. Харків, Україна

${ }^{2}$ Харківська медична академія післядипломної освіти, м. Харків, Україна

Вивчено частоту призначення комбінацій антигіпертензивних препаратів та іiі зміни на різних етапах спостереження у 60 пацієнтів 3 важкоконтрольованою артеріальною гіпертензією (ВАГ) (32 чоловіки та 28 жінок) у віці 59,0 $\pm 9,4$. Всі пацієнти випадковим чином були розділені на дві підгрупи: 3 біологічним зворотним зв'язком (Б33) в контурі метрономізованного дихання (МД) (33 пацієнтів) - основна підгрупа та підгрупа порівняння (27 пацієнтів). Встановлено, що у пацієнтів 3 ВАГ у підгрупі пацієнтів 3 Б3З в контурі МД зазначається скорочення чотирикомпонентниї антигіпертензивної терапії до трикомпонентної, а в підгрупі порівняння зростає частота призначення чотирьохкомпонентної терапії. При цьому встановлено, що доповнення медикаментозної терапії регулярними сеансами БОС в контурі МД сприяє потенціювання антигіпертензивного ефекту у пацієнтів з ВАГ. Робиться висновок, що БЗ3 в контурі МД під контролем параметрів варіабельності серцевого ритму (ВСР) може бути використана як технологія підвищення ефективності контролю артеріального тиску при ВАГ.

КЛЮЧОВІ СЛОВА: важко контрольована артеріальна гіпертензія, варіабельність серцевого ритму, біологічний зворотний зв'язок, метрономізоване дихання 


\section{ЧАСТОТА НАЗНАЧЕНИЯ КОМБИНАЦИЙ АНТИГИПЕРТЕНЗИВНЫХ ПРЕПАРАТОВ У ПАЦИЕНТОВ С ТРУДНОКОНТРОЛИРУЕМОЙ АРТЕРИАЛЬНОЙ ГИПЕРТЕНЗИЕЙ НА ФОНЕ ПРОВЕДЕНИЯ СЕАНСОВ БИОЛОГИЧЕСКОЙ ОБРАТНОЙ СВЯЗИ В КОНТУРЕ МЕТРОНОМИЗИРОВАННОГО ДЫХАНИЯ}

Тимоченко Е. С. ${ }^{1}$, Яблучанский Н. И. ${ }^{1}$ Бильченко А. В. ${ }^{1,2}$

${ }^{1}$ Харьковский национальный университет имени В. Н. Каразина, г. Харьков, Украина

${ }^{2}$ Харьковская медицинская академия последипломного образования, г. Харьков, Украина

Изучена частота назначения комбинаций антигипертензивных препаратов и ее изменения на различных этапах наблюдения у 60 пациентов с трудноконтролируемой артериальной гипертензией (ТАГ) (32 мужчины и 28 женщин) в возрасте 59,0 9 9,4. Все пациенты случайным образом были разделены на две подгруппы: с биологической обратной связью (БОС) в контуре метрономизированного дыхания (МД) и вариабельности сердечного ритма (ВСР) (33 пациентов) основная подгруппа, подгруппа сравнения (27 пациентов). Установлено, что у пациентов с ТАГ в подгруппе пациентов с БОС в контуре МД отмечается сокращение четырехкомпонентной антигипертензивной терапии до трехкомпонентной, а в подгруппе сравнения возрастает частота назначения четырехкомпонентной терапии. При этом установлено, что дополнение медикаментозной терапии регулярными сеансами БОС в контуре МД способствует потенцированию антигипертензивного эффекта у пациентов с ТАГ. Делается вывод, что БОС в контуре МД под контролем параметров ВСР может быть использована как технология повышения эффективности контроля АД при ТАГ.

КЛЮЧЕВЫЕ СЛОВА: трудноконтролируемая артериальная гипертензия, вариабельность сердечного ритма, биологическая обратная связь, метрономизированное дыхание

\section{INTRODUCTION}

Currently, treatment of difficult-to-control arterial hypertension (DTCAH) is an important problem due to the widespread prevalence of patients with DTCAH (30.4-31.8\% of the total population of patients with hypertension) [1], rapid progression of target organ damage and a high risk of cardiovascular events [2].

DTCAH is characterized by the inability to achieve target blood pressure values, despite the appointment of three or more antihypertensive drugs, including diuretics [3]. Due to the absence of randomized clinical trials, the selection of therapy for persons with TAG occurs empirically, taking into account national recommendations for the treatment of hypertension [4]. The best treatment strategy in this case is to select a combination of antihypertensive drugs, which will affect the various links of pathogenesis and physiological mechanisms of hypertension, as well as take into account the comorbidity of a particular patient.

\section{OBJECTIVE}

The aim of the work is to study the change in the frequency of prescribing combinations of antihypertensive drugs used in patients with DTCAH on the background of biofeedback (BFB) in loop of heart rate variability (HRV) and paced breathing $(\mathrm{PB})$.

\section{MATERIALS AND METHODS}

On the clinical base of the Kharkov city outpatient clinic No. 24 and the State Institution «Kharkov Clinical Hospital for Railway Transport No. 1» 60 patients with DTCAH were examined (32 men and 28 women). Average age is $59,0 \pm 9,4$ years. All patients were ran-domly divided into two subgroups: with BFB in the loop of paced breathing (33 patients) - basic subgroup, subgroup of comparisons (27 patients).

The inclusion criteria in the study were any stage and degree of arterial hypertension $(\mathrm{AH})$. The criterion of DTCAH was the presence of a persistent increase in BP above the target level, despite the simultaneous use of three or more antihypertensive drugs of various classes in adequate therapeutic doses, including a diuretic.

Exclusion criteria were heart failure functional class IV, acute coronary syndrome, rhythm and conduction disorders, diabetes mellitus, chronic respiratory insufficiency, bronchial asthma, chronic obstructive pulmonary diseases, peptic ulcer and duodenal ulcer at the stage of exacerbation, systemic diseases of connective tissue, tumors.

Drug therapy was carried out according to the Ukrainian recommendations on the management of patients with AH [4]. Taking into account the degree of severity of 
hypertension, the presence of target organ damage and concomitant pathology in patients with DTCAH one of the following combinations of antihypertensive drugs was prescribed: Inhibitor of angiotensin converting enzyme (ACE)/blockers of the reninangiotensin-aldosterone system (RAAS) + calcium channel blocker (CCB) + diuretic; ACE inhibitor/blocker of the RAAS + CCB + diuretic + antagonist of mineralocorticoids; Beta-blocker + ACE inhibitor/blocker of the $\mathrm{RAAS}+\mathrm{CCB}+$ diuretic; $\mathrm{ACE}$ inhibitor/blocker of the RAAS + CCB + diuretics + hypotensive drugs of the central action.

BFB was carried out on the computer diagnostic complex CardioLab 2009 («HAIMedica», Ukraine) with the module «Biofeedback», including software-related visual-sonic metronome breathing and dynamic algorithm for determining the current values of HRV parameters, changing under the influence of PB. The breathing rate was set by the «Biofeedback» software module.

Statistical processing was carried out using Microsoft Excel. Qualitative variables described by relative values were used for statistical evaluation of the results: $\%$ and their deviation $-\sigma$. The accuracy of differences between groups is determined by the parametric Student's T-test. The expected result was determined by the level of reliability $p<0.05$.

\section{RESULTS AND DISCUSSION}

In table 1 the frequency of prescribing combinations of antihypertensive drugs used in patients with DTCAH in the subgroup of patients with $\mathrm{BFB}$ in the loop of $\mathrm{PB}$ and the subgroup of comparison at the observation stages $-3,6$ months and a year is presented.

Frequency of administration of antihypertensive drug combinations in patients

Table 1 with difficult-to-control hypertension during treatment $(\% \pm \sigma)$

\begin{tabular}{|c|c|c|c|c|c|c|c|c|}
\hline \multirow{4}{*}{$\begin{array}{c}\text { Combinations of } \\
\text { antihypertensive drug }\end{array}$} & \multicolumn{8}{|c|}{ Subgroups of patients } \\
\hline & \multicolumn{4}{|c|}{ Patients with $\mathrm{BFB}$ in the loop of $\mathrm{PB}$} & \multicolumn{4}{|c|}{$\begin{array}{l}\text { Comparison subgroup (BFB without } \\
\text { PB) }\end{array}$} \\
\hline & \multicolumn{8}{|c|}{ Stages of therapy } \\
\hline & $\begin{array}{l}\text { Before } \\
\text { treatment }\end{array}$ & $\begin{array}{c}3 \\
\text { month }\end{array}$ & $\begin{array}{c}6 \\
\text { month }\end{array}$ & 1 year & $\begin{array}{l}\text { Before } \\
\text { treatment }\end{array}$ & $\begin{array}{c}3 \\
\text { month }\end{array}$ & $\begin{array}{c}6 \\
\text { month }\end{array}$ & 1 year \\
\hline $\begin{array}{c}\text { ACE inhibitor/blocker } \\
\text { of the RAAS + CCB + } \\
\text { diuretic }(\% \pm \sigma)\end{array}$ & $\begin{array}{c}39,5 \pm \\
4^{*}\end{array}$ & $\begin{array}{c}44,3 \pm \\
5\end{array}$ & $\begin{array}{c}46,3 \pm \\
4\end{array}$ & $45,5 \pm 3$ & $\begin{array}{c}42,4 \pm \\
5 * *\end{array}$ & $\begin{array}{c}28,3 \pm \\
6\end{array}$ & $\begin{array}{c}25,3 \pm \\
2\end{array}$ & $\begin{array}{c}19,2 \pm \\
4\end{array}$ \\
\hline $\begin{array}{l}\text { ACE inhibitor/blocker } \\
\text { of the RAAS + CCB + } \\
\text { diuretic + antagonist of } \\
\text { mineralocorticoids } \\
(\% \pm \sigma)\end{array}$ & $\begin{array}{c}33,3 \pm 3 \\
*\end{array}$ & $\begin{array}{c}33,3 \pm \\
3\end{array}$ & $\begin{array}{c}34,3 \pm \\
4\end{array}$ & $36 \pm 4$ & $21 \pm 3 * *$ & $45 \pm 3$ & $48 \pm 5$ & $50 \pm 4$ \\
\hline $\begin{array}{c}\text { Beta-blocker }+ \text { ACE } \\
\text { inhibitor/blocker of the } \\
\text { RAAS }+ \text { CCB }+ \\
\text { diuretic }(\% \pm \sigma)\end{array}$ & $\begin{array}{c}24,2 \pm \\
3 *\end{array}$ & $\begin{array}{c}20,6 \pm \\
3\end{array}$ & $\begin{array}{c}19,4 \pm \\
2\end{array}$ & $18,5 \pm 2$ & $\begin{array}{l}34,6 \pm 4 \\
* *\end{array}$ & $\begin{array}{c}21,1 \pm \\
3\end{array}$ & $\begin{array}{c}18,4 \pm \\
5\end{array}$ & $20 \pm 3$ \\
\hline $\begin{array}{l}\text { ACE inhibitor/blocker } \\
\text { of the RAAS + CCB + } \\
\text { diuretics + hypotensive } \\
\text { drugs of the central } \\
\text { action }(\% \pm \sigma)\end{array}$ & $3 \pm 2 *$ & $1,8 \pm 2$ & $0 \pm 0$ & $0 \pm 0$ & $2 \pm 1 * *$ & $5,6 \pm 3$ & $8,3 \pm 4$ & $\begin{array}{c}10,8 \pm \\
3\end{array}$ \\
\hline
\end{tabular}

Both groups of patients before the beginning of the séances were dominated by the administration of a combination ACE inhibitor/blocker of the RAAS + CCB + diuretic. In the subgroup of patients with $\mathrm{BFB}$ in the loop of $\mathrm{PB}$ combinations of $\mathrm{ACE}$ inhibitor/blocker of the RAAS + CCB + diuretic + antagonist of mineralocorticoids, beta-blocker + ACE inhibitor/blocker of the RAAS + CCB + diuretic, ACE inhibitor/blocker of the RAAS + CCB + diuretic + hypotensive drugs of the central action were less frequently prescribed. The ratio of prescription of these combinations of drugs in the subgroup with 
BFB in the loop of PB was 13:11:8:1, at the stage of 3 month observation $24,6: 18,5: 11,4: 1$, at the stage of 6 month observation - 3:5,7:1,8:1 and at the stage of annual observation this ratio was 2,5:1,9:1: 0 . This indicates that the dominance of the assignment of combination ACE inhibitor/blocker of the RAAS + CCB + diuretic was preserved, and also it was noted the declining trend in antihypertensive therapy from four-component to three-component. Frequency of assignment combination which includes beta-blocker + ACE inhibitor/blocker of the RAAS + CCB + diuretic decreased in 1,3 times. Combination of ACE inhibitor/blocker of the RAAS + CCB + diuretic + hypotensive drugs of the central action at the annual stage of treatment wasn't use.

In the subgroup of comparison, the initial ratio of combinations of antihypertensive drugs changed from $21,2: 10,5: 17,3: 1$ to $5: 8: 4.8: 1$ at the three - month stage, $7: 4,6: 2,2: 1$-at the semiannual stage and by the end of the year of observation it was $1,7: 4,6: 1,8: 1$. At the annual stage of therapy, the predominant combination was a combination of ACE inhibitor/RAAS blocker + $\mathrm{BCC}+$ diuretic + mineralocorticoid antagonist, the frequency of administration increased by 2,4 times. There was also an increase of administration of combination ACE inhibitor/blocker of the RAAS + $\mathrm{CCB}+$ diuretics + anti-hypertensive drugs of central action (in 5,4 times). On the contrary, the frequency of administration of combination ACE inhibitor/RAAS blocker + BKK + diuretic decreased by 2,2 times, which demonstrates the predominance of four-component antihypertensive therapy at the annual stage in patients with DTCAH without PB.

The obtained results, according to which the addition of drug therapy with BFB in the loop of PB allows achieving better blood pressure control in patients with DTCAH, are in accordance with the data in patients with controlled AH [5-7]. However, publications on the effectiveness of BFB in the loop of $\mathrm{PB}$ in patients with DTCAH, are absent in the literature.

Our observations confirm the need for combined antihypertensive therapy in patients with DTCAH. The addition of drug therapy by regular BFB sessions in the loop of PB has an additional effect on the neurohumoral regulation, which contributes to the potentiation of the antihypertensive effect.

The results show that the addition of antihypertensive therapy by BFB in the loop of HRV and PB reduces the number of prescribed drugs.

\section{CONCLUSIONS}

1. The addition of drug therapy with regular BFB sessions in the loop of $\mathrm{PB}$ contributes to the potentiation of the antihypertensive effect in patients with DTCAH.

2. There is reduction of four-component antihypertensive therapy to three-component in the subgroup of patients with BFB in the loop of PB. On the contrary in the comparison subgroup the frequency of administration of four-component therapy increases.

3. BFB in the loop of HRV and PB control can be used as a technology to improve the effectiveness of control blood pressure in patients with DTCAH.

\section{PROSPECTS FOR FURTHER RESEARCHES}

In the future, it seems appropriate to study the dynamics of parameters of BFB and blood pressure in patients with the DTCAH at various stages of treatment.

\section{REFERENCES}

1. Systolic and diastolic short-term blood pressure variability and its determinants in patients with controlled and uncontrolled hypertension: A retrospective cohort study / Martino F. Pengo, Giacomo Rossitto, Valeria Bisogni [et. al.] // Blood Pressure -2015. - No. 24 (2). - P. 124-129.

2. Muntner P, Davis BR, Cushman WC, Bangalore S, Calhoun DA, Pressel SL, et al. Treatment-resistant hypertension and the incidence of cardiovascular disease and end-stage renal disease: results from the antihypertensive and lipid-lowering treatment to prevent heart attack trial (ALLHAT). Hypertension (2014) 64:1012-21.

3. ESH/ESC Guidelines for the management of arterial hypertension: The Task Force for the management of arterial hypertension of the European Society of Hypertension (ESH) and of the European Society of Cardiology (ESC) / Giuseppe Mancia, Robert Fagard, Krzysztof Narkiewicz [et al.]. // Journal of Hypertension. - 2013. - No. 31. - P. 1281-1187. 
4. Unifikovaniy klinichniy protokol pervinnoyi, ekstrennoyi ta vtorinnoyi (spetsializovannoyi) dopomogi «Arterialna gipertenziya». - Praktichniy likar. - 2013. - No. 2. - stor.43-51).

5. Kulik A. L. Biofeedback and modern clinical practice. / A. L. Kulik, N. I. Yabluchanskiy // The Journal of V. N. Karazin Kharkiv National University. Series «Medicine». - 2011. - No. 22 (975). - P. 82-93.

6. Shmidt E. Yu. Closed loop biofeedback of heart rate variability and paced breathing efficacy evaluation in patients with arterial hypertension / E. Yu. Shmidt, A. L. Kulik, A. V. Martyinenko [et al.] // The Journal of V. N. Karazin Kharkiv National University. Series «Medicine». - 2011. - No. 22 (975). - P. 63-67.

7. Belal S. A. S. The influence of biofeedback sessions in closed loop of heart rate variability and paced breathing on systolic blood pressure control during standart drug therapy in patients with arterial hypertension / S. A. S. Belal, N. A. Vodyanitskaya, M. I. Yabluchanskiy // The Journal of V. N. Karazin Kharkiv National University. Series «Medicine». - 2015. - No. 29. - P. 11-21. 